\title{
Children Family Break and Access to Health Care Law: What Knowledge and Attitudes in the City of Mbujimayi Democratic Republic of Congo
}

\author{
Anaclet Mbuyi Mishinda1, Jean Christophe Bukasa Tshilonda ${ }^{*}$, Guillaume Kabongo Mwamba ${ }^{1}$, \\ Valentin Kabambi Bukasa1, André Mutombo Kabamba², Stany Wembonyama Okitotsho ${ }^{3}$ \\ ${ }^{1}$ Division of Nursing, Higher Institute of Medical Techniques Mbujimayi, Mbujimayi, Democratic Republic of the Congo \\ ${ }^{2}$ Faculty of Medicine, University of Mbujimayi Official, Mbujimayi, Democratic Republic of the Congo \\ ${ }^{3}$ School of Public Health, Faculty of Medicine, University of Lubumbashi, Lubumbashi, Democratic Republic of the Congo \\ Email: ${ }^{*}$ jcbukasa4@gmail.com
}

How to cite this paper: Mishinda, A.M., Tshilonda, J.C.B., Mwamba, G.K., Bukasa, V.K., Kabamba, A.M. and Okitotsho, S.W. (2019) Children Family Break and Access to Health Care Law: What Knowledge and Attitudes in the City of Mbujimayi Democratic Republic of Congo. Open Access Library Journal, 6: e5386.

https://doi.org/10.4236/oalib.1105386

Received: April 10, 2019

Accepted: July 2, 2019

Published: July 5, 2019

Copyright (๑) 2019 by author(s) and Open Access Library Inc.

This work is licensed under the Creative Commons Attribution International License (CC BY 4.0).

http://creativecommons.org/licenses/by/4.0/

\begin{abstract}
Introduction: In the Democratic Republic of Congo, the right to health care is recognized to all children at both constitutional principles of the law on protection of the latter. Despite the existence of these instruments, access to health care continues to be a problem again. Thus, our study focuses on children with family breakdown and the right of access to health care: What about knowledge and attitudes in Mbujimayi/Democratic Republic of Congo. Methods: The study is the quantitative correlational type and focused on 600 children from broken homes in the city of Mbujimayi. She performed for a period of four months which is from 18 March to 18 July 2018. A questionnaire consisting of closed and open questions was used as an instrument for data collection. The Epi-Info software version 3.5 in 2010 was used for data analysis. Results: The majority of children in family breakdown is composed of those with more than 14 years with (52.8\%); the average age is 15.5 years; $67.8 \%$ are male; $53 \%$ live east of the City of Mbujimayi; $60.5 \%$ are non-monogamous families; $53.8 \%$ are without levels; $67.5 \%$ are Christian and $71 \%$ cannot read or write. Conclusion: Knowledge of the right of access to health care and the question that access to health care den is an exclusive right granted to children from broken families is low. The attitude of children from broken front right of access to health care Mbujimayi is negative. So to improve this knowledge and attitudes, we suggest that parents support their responsibilities by supervising their children. Social actors and other stakeholders in the protection of children, help them reintegrate into society by providing them with a minimum of education/training to continue to do
\end{abstract}


their fieldwork by sensitizing these children on their rights and especially on the right of access to health care to the Congolese State.

\section{Subject Areas}

Nursing, Public Health

\section{Keywords}

Children from Broken Homes, Access to Health Care, Access to Health Care

\section{Introduction}

Access to health care is a right of every individual including children. The right of access is a moral imperative directly related to human rights. In the Democratic Republic of Congo, access to health care is still a problem and the universal care coverage for the population in general and children in family breakdown in particular is far from Revenue Is. Thus, the ultimate goal in terms of the right to health and access to health care throughout the world is to ensure universal access to health care to anyone with children [1].

Based on this, the DRC established through the presidency of the republic since 2010 a commission of up to study how to achieve universal coverage of health care for the entire population and took out a law $\mathrm{N}^{\circ} 09 / 001$ of 10/01/20009 concerning child protection [2]: Upon completion of this law in Article 23, it is known to all children whatever the right of access to health care and healthy nutrition. However, the absence of monitoring mechanisms and awareness to this legislation ensures that the child does not yet have that right. In the industrialized countries, access to child health care is estimated at $\pm 70 \%$ and in developing countries, this rate is $30 \%$. According to a study in the DRC about access to children's health care, only $12 \%$ have access to health care [3]. Saving the Children [4] in one of its surveys Mbujimayi about access to basic social services for orphans and vulnerable children (OVC), revealed that $70 \%$ of this population had no access to Health care. Anaclet Mbuyi [5]. In its study Mbujimayi about access to health care as a right of every child without exception found that $19 \%$ of these children had access to health care. Given the precariousness of children's lives in terms of access to basic social services, including health care, and in view of the marginalization of children in family breakdown in our society, only a study on the right of access to care children in a general way and on those at break of family could situate us on the effectiveness of the law $n^{\circ} 09 / 001$ of the 10/01/2009.

\section{Method}

Our study was conducted in the City of Mbujimayi. She was involved 600 children from broken drawn as convenience sample in 15 public places of the city including 8 in the east of the city and 7 west. The method used was the question- 
naire survey supported by the semi-structured interview technique. The questionnaire was used for data collection equipment after having been tested in 5 places including 3 and 2 in the East to the West. The data were collected by 20 previously trained investigators.

In order to analyze the data, percentages and proportions averages were calculated using the Epi-Info software. The links between the independent and dependent variables were tested using the chi-square statistical test $\left(\mathrm{kh}^{2}\right)$. Among the variables considered in this study we have:

1) Dependent variables: Knowledge and attitude of the right of access to health care.

2) Independent variables: socio-demographic and cultural characteristics:

a) sex;

b) age;

c) level of education;

d) residence;

e) family status;

f) literacy.

\section{Ethical Considerations}

The aspects relating to respect for study subjects and their comments were kept anonymous. The data we present reflect that we have collected. Finally, an effort was made not to translate our own feelings in this study.

\section{Results}

1) Results of the descriptive analysis.

2) Results of the bivariate analysis.

\section{Discussion}

\subsection{Results Descriptive Analyzes}

This study aimed to determine the knowledge and attitudes of children from broken front right of access to health care Mbujimayi. The male dominates in our series with $67.8 \%$ vs. $32.2 \%$ for females. The average age of children in our study was 15 years, ranging between 12 and 18 years. 60.5\% of children from broken homes are from non-monogamous families (Tables 1-5). This result corroborates that of Riccardo Luchini [6].

Regarding education, $53.8 \%$ have no level. In terms of religion, $67.5 \%$ of children from broken families are Christian and $71 \%$ of them cannot read or write. These results are in the same direction as those Malemba G [7].

\subsection{Results of the Bivariate Analysis}

In this study, we also check the association between socio-demographic and cultural characteristics and the knowledge and attitudes of children from broken front right of access to health care [8]. 
Table 1. Distribution of subjects by socio-demographic and cultural characteristics.

\begin{tabular}{|c|c|c|c|}
\hline Sex & & Numbers & Percentage \\
\hline & Female & 193 & 32.2 \\
\hline & Male & 407 & 67.8 \\
\hline & Total & 600 & 100.0 \\
\hline \multicolumn{4}{|l|}{ Age } \\
\hline & $<13$ years & 283 & 47.2 \\
\hline & 14 and over & 317 & 52.8 \\
\hline & Total & 600 & 100.0 \\
\hline \multicolumn{4}{|c|}{ Residence } \\
\hline & Eastern Mbujimayi & 318 & 53.0 \\
\hline & West Mbujimayi & 282 & 47.0 \\
\hline & Total & 600 & 100.0 \\
\hline \multicolumn{4}{|c|}{ Family status } \\
\hline & monogamous & 237 & 39.5 \\
\hline & Other & 363 & 60.5 \\
\hline & Total & 600 & 100.0 \\
\hline \multicolumn{4}{|c|}{ Instruction Level } \\
\hline & without level & 323 & 53.8 \\
\hline & Primary & 277 & 46.2 \\
\hline & Total & 600 & 100.0 \\
\hline \multicolumn{4}{|c|}{ Religion } \\
\hline & Christian & 405 & 67.5 \\
\hline & Other & 195 & 32.5 \\
\hline & Total & 600 & 100.0 \\
\hline \multicolumn{4}{|c|}{ Literacy } \\
\hline & Is literate & 174 & 29.0 \\
\hline & Do not read or write & 426 & 71.0 \\
\hline & Total & 600 & 100.0 \\
\hline
\end{tabular}

In relation to knowledge, the absence of the instrument and being a practicing Christian religion are sociodemographic and cultural characteristics that would influence the knowledge of the right of access to health care for children from broken because the values of $(p<0.05)$ [9].

This result regarding the investigation, is due to the fact with minimal instruction, the child whether from the street or other may have a knowledge about the rights and duties in the community. But with religion, this result is at odds with the realities of the Christian church in our society because it is one of the churches that frames most children and is often at the forefront in raising awareness the population on its rights [10]. Taking access to care as exclusive, 
A. M. Mishinda et al.

Table 2. Association between knowledge of the right of access to health care and socio-demographic and cultural characteristics.

\begin{tabular}{|c|c|c|c|c|c|c|}
\hline \multirow{2}{*}{ Feature } & \multirow{2}{*}{ Category } & \multicolumn{2}{|c|}{ Knowledge of the right of access } & \multirow{2}{*}{$x^{2}$} & \multirow{2}{*}{$\mathrm{P}$} & \multirow{2}{*}{ Meaning } \\
\hline & & knows & Do not know & & & \\
\hline \multicolumn{7}{|l|}{ Sex } \\
\hline & Female & 13 & 180 & \multirow{2}{*}{0.471} & \multirow{2}{*}{0.626} & \multirow{2}{*}{ NS } \\
\hline & Male & 34 & 373 & & & \\
\hline \multicolumn{7}{|l|}{ Age } \\
\hline & $11-13$ years & 20 & 263 & \multirow{2}{*}{0.509} & \multirow{2}{*}{0.546} & \multirow{2}{*}{ NS } \\
\hline & 14 and over & 27 & 290 & & & \\
\hline \multicolumn{7}{|l|}{ Residence } \\
\hline & Eastern Mbujimayi & 26 & 292 & \multirow{2}{*}{0.110} & \multirow{2}{*}{0.763} & \multirow{2}{*}{ NS } \\
\hline & West Mbujimayi & 21 & 261 & & & \\
\hline \multicolumn{7}{|c|}{ Family status } \\
\hline & Monogamous & 19 & 218 & \multirow{2}{*}{0.018} & \multirow{2}{*}{0.892} & \multirow{2}{*}{ NS } \\
\hline & Other & 28 & 335 & & & \\
\hline \multicolumn{7}{|c|}{ Level of education } \\
\hline & Without level & 16 & 307 & \multirow{2}{*}{8.036} & \multirow{2}{*}{0.004} & \multirow{2}{*}{$S$} \\
\hline & Primary & 31 & 246 & & & \\
\hline \multicolumn{7}{|l|}{ Religion } \\
\hline & Christian & 41 & 364 & \multirow{2}{*}{9.025} & \multirow{2}{*}{0.0026} & \multirow{2}{*}{ S } \\
\hline & Other & 6 & 189 & & & \\
\hline \multicolumn{7}{|l|}{ Literacy } \\
\hline & Is literate & 18 & 156 & \multirow{2}{*}{2.141} & \multirow{2}{*}{0.143} & \multirow{2}{*}{ NS } \\
\hline & Do not read or write & 26 & 387 & & & \\
\hline
\end{tabular}

Table 3. Association between access to care as exclusive and demographics and cultural.

\begin{tabular}{|c|c|c|c|c|c|c|}
\hline \multirow{2}{*}{ Feature } & \multirow{2}{*}{ Category } & \multicolumn{2}{|c|}{ Access to care as the exclusive right } & \multirow{2}{*}{$x^{2}$} & \multirow{2}{*}{$\mathrm{P}$} & \multirow{2}{*}{ Meaning } \\
\hline & & Yes & No & & & \\
\hline \multicolumn{7}{|l|}{$\operatorname{Sex}$} \\
\hline & Female & 145 & 48 & \multirow{2}{*}{7.862} & \multirow{2}{*}{0.005} & \multirow{2}{*}{ S } \\
\hline & Male & 259 & 148 & & & \\
\hline \multicolumn{7}{|l|}{ Age } \\
\hline & $11-13$ years & 186 & 97 & \multirow{2}{*}{0.427} & \multirow{2}{*}{0.434} & \multirow{2}{*}{ NS } \\
\hline & 14 and over & 218 & 99 & & & \\
\hline \multicolumn{7}{|c|}{ Residence } \\
\hline & Eastern Mbujimayi & 180 & 138 & \multirow{2}{*}{35.413} & \multirow{2}{*}{0.000} & \multirow{2}{*}{ S } \\
\hline & West Mbujimayi & 224 & 58 & & & \\
\hline \multicolumn{7}{|c|}{ Family status } \\
\hline & Monogamous & 153 & 84 & \multirow{2}{*}{1.631} & \multirow{2}{*}{0.442} & \multirow{2}{*}{ NS } \\
\hline & Other & 251 & 112 & & & \\
\hline \multicolumn{7}{|c|}{ Level of education } \\
\hline & Without level & 235 & 88 & \multirow{2}{*}{10.186} & \multirow{2}{*}{0.006} & \multirow{2}{*}{$S$} \\
\hline & Primary & 169 & 108 & & & \\
\hline \multicolumn{7}{|l|}{ Religion } \\
\hline & Christian & 280 & 175 & \multirow{2}{*}{1.840} & \multirow{2}{*}{0.174} & \multirow{2}{*}{ NS } \\
\hline & Other & 124 & 71 & & & \\
\hline \multicolumn{7}{|l|}{ Literacy } \\
\hline & Is literate & 106 & 68 & \multirow[b]{2}{*}{4.583} & \multirow[b]{2}{*}{0.035} & \multirow[b]{2}{*}{$S$} \\
\hline & $\begin{array}{l}\text { Do not read or } \\
\text { write }\end{array}$ & 298 & 128 & & & \\
\hline
\end{tabular}


Table 4. Association between accepting access to care as exclusive, demographics and cultural.

\begin{tabular}{|c|c|c|c|c|c|c|}
\hline \multirow[t]{2}{*}{ Feature } & \multirow[t]{2}{*}{ Category } & \multicolumn{2}{|c|}{$\begin{array}{l}\text { Supports access } \\
\text { to care is a right }\end{array}$} & \multirow[t]{2}{*}{$x^{2}$} & \multirow[t]{2}{*}{$\mathrm{P}$} & \multirow[t]{2}{*}{ Meaning } \\
\hline & & Accepted & Do not accept & & & \\
\hline \multicolumn{7}{|l|}{ Sex } \\
\hline & Female & 175 & 18 & \multirow{2}{*}{6.143} & \multirow{2}{*}{0.013} & \multirow{2}{*}{$S$} \\
\hline & Male & 338 & 69 & & & \\
\hline \multicolumn{7}{|l|}{ Age } \\
\hline & $11-13$ years & 237 & 46 & \multirow{2}{*}{1.330} & \multirow{2}{*}{0.296} & \multirow{2}{*}{ NS } \\
\hline & 14 and over & 276 & 41 & & & \\
\hline \multicolumn{7}{|c|}{ Residence } \\
\hline & Eastern Mbujimayi & 258 & 60 & \multirow{2}{*}{10.412} & \multirow{2}{*}{0.002} & \multirow{2}{*}{$S$} \\
\hline & West Mbujimayi & 255 & 27 & & & \\
\hline \multicolumn{7}{|c|}{ Family status } \\
\hline & Monogamous & 206 & 31 & \multirow{2}{*}{0.637} & \multirow{2}{*}{0.414} & \multirow{2}{*}{ NS } \\
\hline & Other & 307 & 56 & & & \\
\hline \multicolumn{7}{|c|}{ Level of education } \\
\hline & Without level & 288 & 35 & \multirow{2}{*}{7.615} & \multirow{2}{*}{0.022} & \multirow{2}{*}{ NS } \\
\hline & Primary & 261 & 82 & & & \\
\hline \multicolumn{7}{|l|}{ Religion } \\
\hline & Christian & 352 & 53 & \multirow{2}{*}{2.394} & \multirow{2}{*}{0.302} & \multirow{2}{*}{ NS } \\
\hline & Other & 161 & 34 & & & \\
\hline \multicolumn{7}{|l|}{ Literacy } \\
\hline & Is literate & 145 & 29 & \multirow{2}{*}{0.928} & \multirow{2}{*}{0.37} & \multirow{2}{*}{ NS } \\
\hline & Do not read or write & 373 & 53 & & & \\
\hline
\end{tabular}

we find that gender, residence and education level would influence this exclusive right, because the values of $(p<0.05)$. These results explain that the lack of education and the fact of living in a neighborhood as is the case of the East of the City of Mbujimayi that these children are unaware that access to care is an exclusive right of every child without forgetting those in family breakdown [11].

Related attitudes, gender and the fact of living in the east of the city of Mbujimayi would influence negatively children from broken families to accept that access to health care is an exclusive right granted to all children without distinction as, the values of $(\mathrm{p}<0.05)$. These results are explained by the fact that the eastern city of Mbujimayi abound less schools and is counted among the most remote corners and the less fortunate of the city [12]. As for being ready to assert this right of access, gender, the fact of living in the east of the city and would influence negatively education the right of access to health care as the exclusive legal right any child. These results complement that of access to care as the exclusive 
Table 5. Association between being ready to claim the right of access to health care and socio-demographic and cultural characteristics.

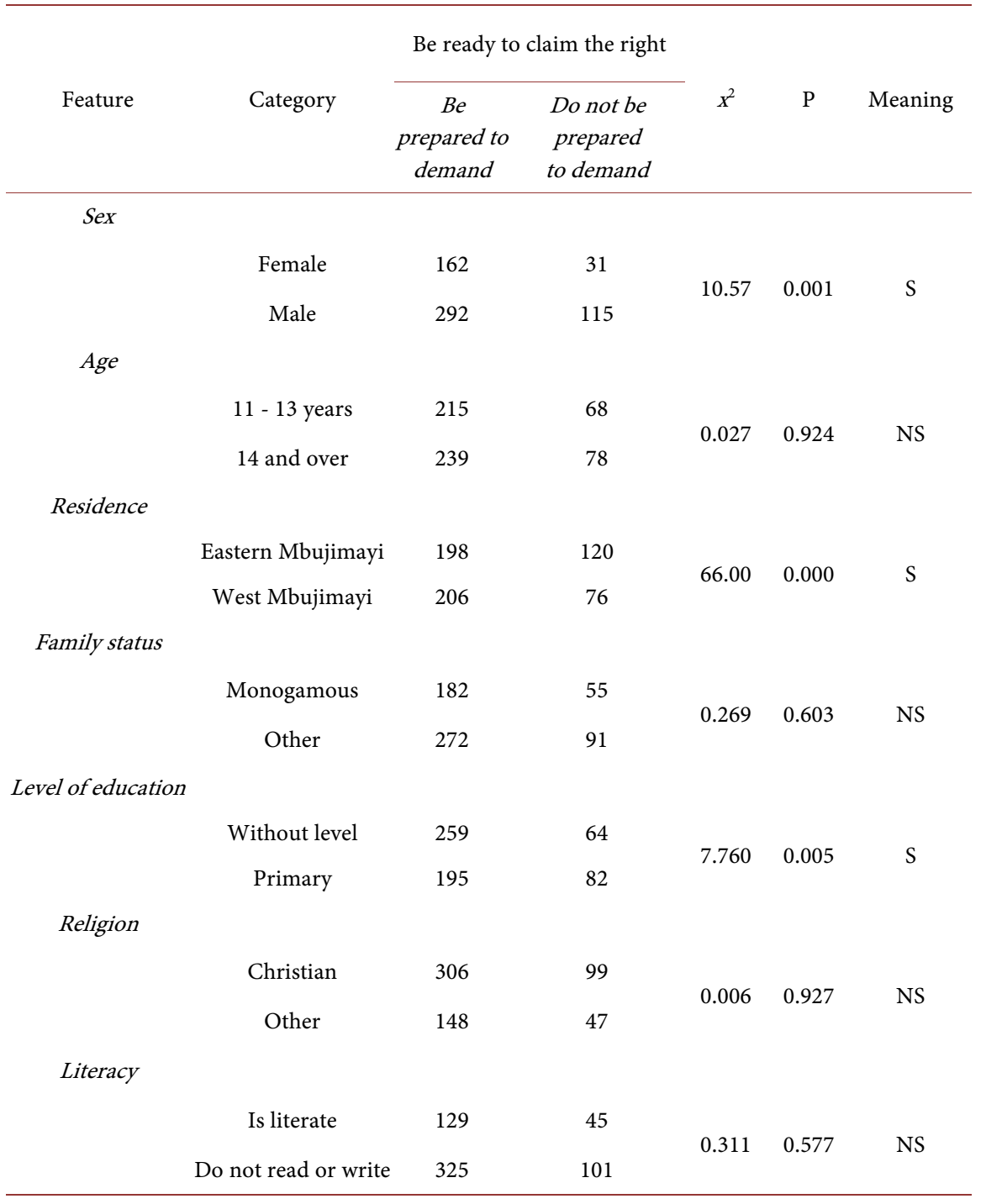

legal right to child roof after Law No. 09/001 of 10/01/2009 [13].

\section{Conclusion}

Knowledge of the right of access to health care and the question that access to health care den is an exclusive right granted to children from broken families, which is low. The attitude of children from broken front right of access to health care Mbujimayi is negative. So to improve this knowledge and attitudes; we suggest that parents support their responsibilities by supervising their children. Social actors and other stakeholders in the protection of children, help them reintegrate into society by providing them with a minimum of education/training. to contribute to doing their fieldwork by sensitizing these children about their rights and especially about the right of access to health care to the Congolese State. 


\section{Conflicts of Interest}

The authors declare no conflicts of interest regarding the publication of this paper.

\section{References}

[1] Melk, O. (2005) Right to Health, Center Europe Third World, New York.

[2] Stéphane, T. (1998) In Search of Street Children, the Children's Network, Living Space Street, Distance and Shoes Trape. Fayard, Paris.

[3] President of the DR (2010) Decision No 01/07/2010 on the Establishment of a Commission to Prepare the Draft Law on Universal Coverage of Health Care, Kinshasa.

[4] President of the DRC (2010) Decision No 15/09/2010 on the Appointment of Members of the Commission Responsible for Drafting the Draft Law on Universal Coverage of Health Care, Kinshasa.

[5] President of the DRC (2010) Law No. 09/001 of 10/01/2009. The Official Newspaper of the DRC, Kinshasa.

[6] WHO (2009) Health Statistics of the World.

[7] UNICEF/Samu Social Congo (2010) Street Child in Africa, Brazzaville.

[8] Save the Children (2010) Improving Protection, Access to Basic Social Services and Community Integration, Kinshasa.

[9] Mbuyi, A., et al. (2010) Child in Family Breakdown and the Right to Health: Rates and Factors Limiting Access to Health Care in Relation to Law No. 09/001 of 10/01/2009 in the City of Mbuji Mayi.

[10] Riccardo, L. (2014) Sociology of Survival of the Street Child in Africa. Presses universitaires de France (PUF), Paris.

[11] Malemba, G. (2003) Child in the Street without the Family and Non-Family. PUL, Lubumbashi.

[12] President of the DRC (2010) Constitution of the Democratic Republic of Congo. The Official Journal of the DRC, Kinshasa, 2006.

[13] UNICEF/UN AIDS (2010) Advocacy for Access to Care for Vulnerable, Improve Access to Care in Developing Countries, New York, 2001. 